\title{
ALTITUDINAL DISTRIBUTION OF POPULATION AND SETTLEMENTS IN THE CARPATHIAN MOUNTAIN SPACE. CASE STUDY: ROMANIAN CARPATHIANS
}

\author{
Mădălin-Sebastian LUNG* \\ Babeș-Bolyai University, Doctoral School of Geography, Faculty of Geography, 400006, Cluj-Napoca, \\ Romania, e-mail: lungmadalin@yahoo.com
}

\author{
Luca DIACONESCU \\ University of Oradea, Doctoral School of Geography, Oradea, Romania, \\ e-mail: diaconesculuca@yahoo.ro
}

Citation : Lung M.-S., Diaconescu L. (2019). Altitudinal Distribution of Population and Settlements in the Carpathian Mountain Space. Case Study : Romanian Carpathians. Revista Română de Geografie Politică, 21(1), 1-17. https://doi.org/10.30892/rrgp.211101-324

\begin{abstract}
The purpose of this study is to carry out a statistic on the altitude distribution of population and settlements in the Romanian Carpathians. These mountains are inhabited from the earliest historical periods. They offered the continuity of the Paleolithic population to the contemporary. 7 altitudes classes, respectively $56-100 \mathrm{~m}, 100-200 \mathrm{~m}$, $200-300 \mathrm{~m}, 300-500 \mathrm{~m}, 500-750 \mathrm{~m}, 750-1000 \mathrm{~m}$ and $1,000-1,500 \mathrm{~m}$ were established for the achievement of the research. The data used for the study were those of the last 20th Century Census (1992) and the data of the last $21^{\text {st }}$ Century Census (2011). Also, for some incursions in the explanation of demographic phenomena regarding the demographic evolution of settlements, the census of 1880,1900 and 1930 were used. After processing data through the ArcGis 10.3 and Microsoft Excel 2013, a series of dysfunctions resulted. The Romanian Carpathians depopulated in the period 1992-2011, with about 435,000 inhabitants. All 7 elevation classes decreased demographical, with weights between $10 \%-27 \%$. The majority of the population is located between $500-750$ metres, which is lost to the highest numerical demographic, about 150,000 inhabitants. Under percentage ratio, the largest demographic decrease was $27 \%$ for settlements between $56-100$ meters altitude. As a consequence, the space of the Romanian Carpathians faces risk demographic phenomena, such as depopulation.
\end{abstract}

Key words: distribution, altitude, demography, settlements, Romanian Carpathians, Carpathian Mountain Space 


\section{INTRODUCTION}

The purpose of the study was to carry out a statistic on the altitudinal distribution of the population and settlements in the Romanian Carpathians. These mountains have been a place of life for man since the Paleolithic period, with continuity and cycling in their anthropization until the contemporary period. The diversity of basement resources has trained allohtone populations, which have been driven by the mirage of riches. The population expanded from the lowest altitudes, from the terraces of the hydrographic courses to the highest mountain altitudes, to over 1,000 meters altitude. The Romanian Carpathians are divided into three major groups: the Eastern Carpathians, the Southern Carpathians and the Western Carpathians. In their territory there are 2,320 localities, distributed unequal altitude (figure 1).

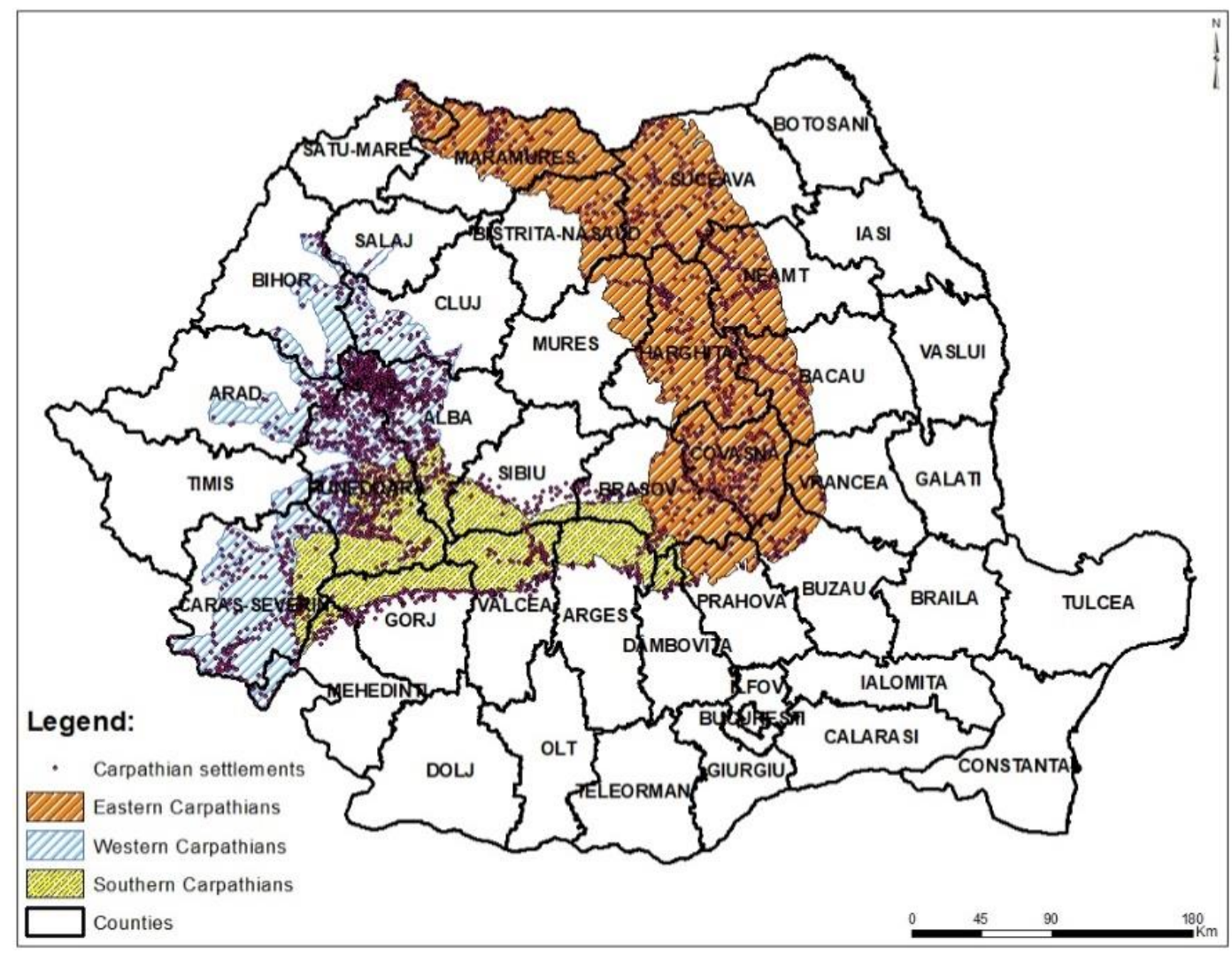

Figure 1. Geographical location of the Romanian Carpathians

(Source: own study)

Basically, this would be a first article aimed at the study of the population and settlements for the entire space of the Romanian Carpathians, in one ensemble, after the end of socialism in 1989. Studies on the carpathian demographic and habitats have been achieved, especially for smaller carpathian territories as dimensions, such as depression (Alexandrescu, 1995; Popa-Bota, 2003; Seer, 2004; Niță, 2007; Constantin, 2011; Holircă, 2014). Also, population and settlements research has shown interest for romanian researchers, with a considerable number of studies focused on various territories (Bizerea, 1970; 
Herman, 2008, 2009; Ionescu, 2009; Lung, 2018; Lung \& Mureşan, 2018; Lung \& Gligor, 2018; Maier, 2001; Misachevici, 2012; Rațiu, 2008; Surd, 1993; Stroia, 2001; Tănasă, 2007). The research of settlements and population was and is a topical topic for researchers from other countries (Findlay, 2003; Josipovic \& Repolusk, 2003; Živković \& Pavlović, 2006; Arsenović et al., 2009; Prioux \& Mazuy, 2009; Kerbler, 2015; Djurkin, 2018).

\section{MATERIAL AND METHODS}

The first step consisted in the morphological delimitation of the Romanian Carpathians. The limit was obtained after the geomorphological map (Posea \& Badea, 1984). Through the ArcGis 10.3 program, the map on the geographical position of the Romanian Carpathians was carried out. The same program was used to reclassify the digital elevation model. To be able to correctly extract the settlements for each elevation step, a reclassification of the digital elevation model was performed. It was only after this process that the correct altitudes and the classification of settlements on the 7 altitudinal steps could be obtained. 2,320 localities of different sizes were incorporated within the limit obtained. After obtaining the altitudes classes, it was passed to the generation of maps on the geographic distribution of settlements for each altitude step.

The next step consisted in procuring statistical data from the National Institute of Statistics for the two census of 1992 and 2011. The data processing was done with Microsoft Excel 2013, following a few graphs on numerical population evolution, percentage decreases and settlement weights on established altitude classes. Data from the census of 1880, 1900 and 1930 were also used to explain demographic evolutions.

\section{RESULTS AND DISCUSSIONS}

For the altitudinal distribution of the population and settlements in the Romanian Carpathians we have established 7 altitudinal classes. The 7 classes are: $56-100 \mathrm{~m}, 100-200 \mathrm{~m}, 200-300 \mathrm{~m}, 300-500 \mathrm{~m}, 500-750 \mathrm{~m}, 750-1000 \mathrm{~m}$ and $1,000-1,500 \mathrm{~m}$.

In the first altitudinal step (56-100 m) 22 localities were identified. In 1992 , the 22 had a population of 42,214 inhabitants. Of the total population of 42,214 inhabitants, 28,520 was the urban population incorporated into three localities: Orșova, Moldova Veche and Măcești, the rest was a rural population. Only two settlements were small in size with less than 500 inhabitants: Divici (382 inhabitants) and Cozla (182 inhabitants). Nine localities included mediumsized settlements with population between 501-1,500 inhabitants (Șușca, Bârza, Radimna, Dubova, Belobreșca, Șvinița, Liubcova, Coronini, Pojejena). The population of the medium settlements was 8,357 inhabitants. Berzasca and Eşelnita were the only two localities to be positioned among the large settlements of more than 1,501 inhabitants, with a population of 1,619 inhabitants, respectively 3,154 inhabitants. Of the 22 localities, 6 (Tişovița, Plavişevița, Drencova, Jupalnic, Tufari, Coramnic) had no inhabitant due to the fact that the waters of the lake of accumulation of Iron Gates, covered households, the population being displaced to the other localities from proximity. Also, some localities like Jupalnic and Coramnic were allied to the urban town of Orşova.

By 2011, the population in this altitude step fell to 30,811 inhabitants. Under the report of the inhabitants, the decrease was 11,403 people, and from a percentage point of view was $27 \%$. The urban population of the three localities 
decreased to 2011, to 19,505 inhabitants (Orșova, Moldova Veche, Măcești). The loss of 9,015 people compared to 1992, meant $31 \%$. The number of small localities increased from 2 to 5 (Șușca 450, Dubova 410, Divici 281, Cozla 86, Drencova 4). Drencova is a new settlement with the repositioning of the river after the rise of the Danube level, following the construction of the reservoir flooded the old settlement. The herd of medium-sized localities was 9, together with 7,510 inhabitants. Eșelnița was the only large-scale locality with 2,565 inhabitants, down from 1992 by 18\%.

From Figure 2 we can see that the settlements in the first altitudinal step are geographically positioned in the lowest hypnosometric part of the Romanian Carpathians, between 56-100 m. Thus, they are grouped in the depressed region in the immediate proximity of the Danube, advancing north on a short distance to the Timiss-Cerna corridor. The settlements were placed on the terraces of the Danube and other smaller tributaries of the river. The population of localities has occupied and still deals with fishing activities, being the main occupation of the demographic component.

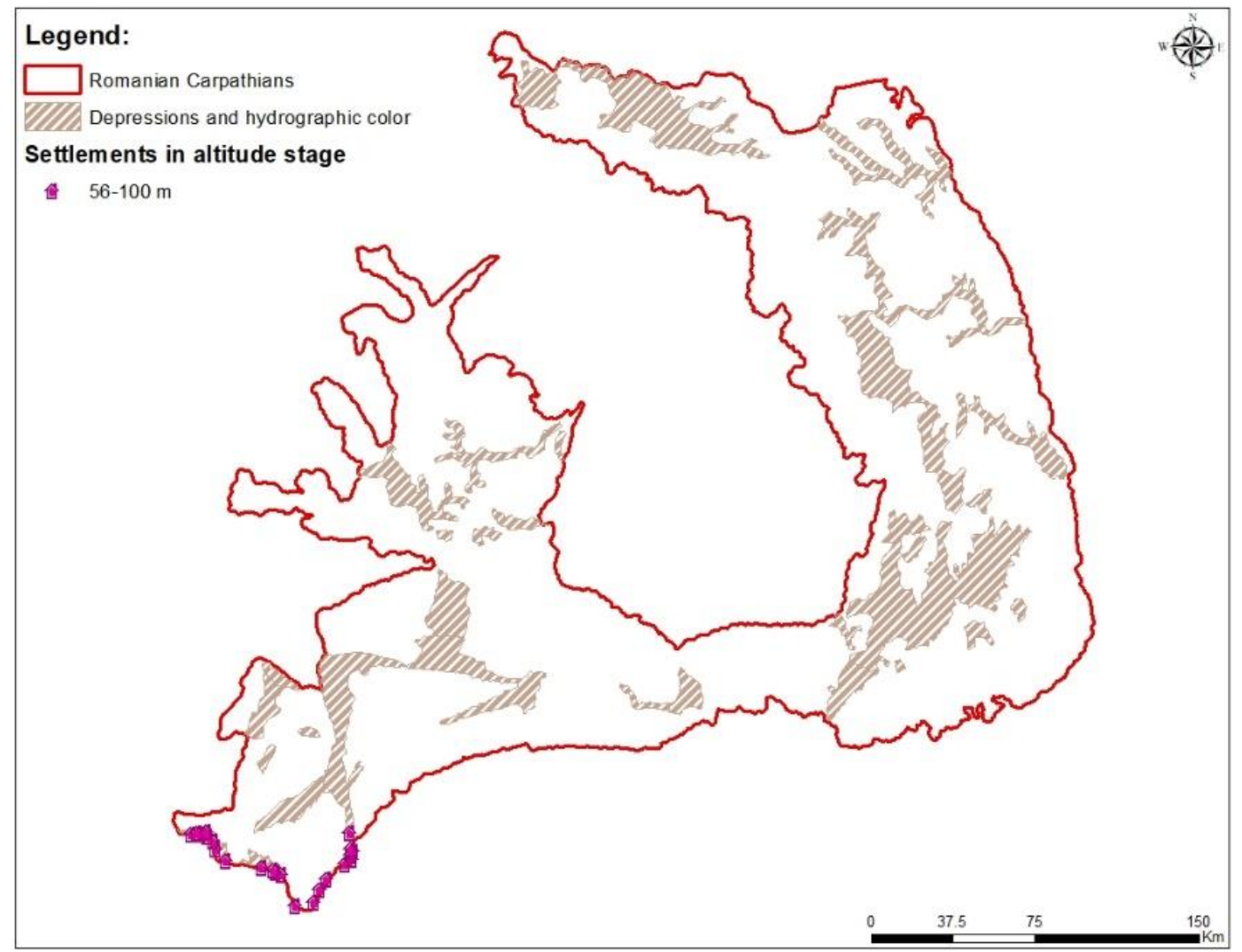

Figure 2. Distribution of settlements between 56-100 meters altitude (Source: own study)

Although it is not the subject of the present study, we would like to mention that the settlements have undergone during the XVIII-XIX centuries, the colonizing stress. The Habsburg authorities wanted to intensify the population of the mountain space, colonizing in the south of Banat Mountains, on the banks of 
the Danube, a number of allohtone populations. Families of german descent were brought to Radimna and Pojejena, and the romanian population was displaced to Belobresca and Liubcova. In the perimeter of Divici, ethnic Italians were colonised. All the domestic populations received from the benefits authorities such as tax exemptions, farmland and others (Țintă Aurel, 1972).

In 1992, in the altitude gauge of 100-200 meters, they lived 181,823 persons in 76 localities, of which 122,418 (67\%) in the urban areas of the 14 localities (Deva, Bocșa, Simeria, Băile Herculane, Moldova Nouă, Pecinișca, Câlnic, Moniom, Jupa, Sântandrei, Sântuhalm, Uroi, Saulesti, Stejar). The number of small localities that had less than 500 inhabitants was 26, cumulating a population of 7,383 people. The herd of medium-sized settlements was slightly lower than that of small settlements. A population of 19,172 people was registered at the level of 21 localities. The largest flock of the rural population in the altitude gauge 100-200 meters for the year 1992, was 28,140 people. This population was comprised in the territory of 12 large localities (Cămârzana, Mehadia, Topleț, Carașova, Bătârci, Tărna Mare, Tur, Orașu Nou, Boinești, Gherța Mare, Sichevița, Vama). Very large settlements, with a number of inhabitants over 4,000 people, were represented by a single locality, Bixad from Satu-Mare County which had 4,710 inhabitants.

After 19 years, the carpathian altitudinal step between 100-200 metres, losing 33,671 people. In 2011, the population was 148,152 , registering $18 \%$ decrease. The urban population decreased from 1992 with 24,686 people reaching 92,347 . The percentage decrease in the urban population was $24 \%$. If 19 years ago, the number of small settlements was 26, in 2011, their number increased to 30 . Out of the 30, we can mention 5 that had fewer than 50 inhabitants (Aliceni 41, Crușovița 41, Valea Sicheviței 36, Camenița 11, Ogașu Podului 7). In 2011, there is no more large-scale settlement. The number of large settlements decreased from 12 to 11 , and the decrease was demographical. The population decreased by $30 \%$, from 28,140 to 19,567 inhabitants.

Localities between 100-200 m occupy marginal and marginal Carpathian territories (figure 3). A first compact group of settlements can be identified in the northwest of the Romanian Carpathians, specifically in the Oaşului Depression. Instead, the rest of the settlements no longer form a habitational group so gathered, being distributed on the southern and western margins of the Banat Mountains and in the south and southwest of the Apuseni Mountains. Basically, the settlements in the southwest of Apuseni revolate around the mountain of the Zarands, respectively in the Mureş corridor.

The number of settlements increases considerably for the altitudinal step of 200-300 metres, reaching 281 localities. In 1992, the 281 owned a population of 487,531 inhabitants. $68 \%$ and 334,921 people lived in the urban area of the 34 localities (Batiz, Bârcea Mare, Bârcea Mică, Brad, Caransebeș, Căciulata, Călan, Călanu Mic, Cărpiniș, Ciclova Montana, Cireșa, Cristur, Geoagiu, Hunedoara, Lancrăm, Nădăștia de Jos, Nădăștia de Sus, Negrești-Oaș, Ohaba Streiului, Orăștie, Oțelu Roșu, Peștișu Mare, Răcăștia, Reșița, Sâncrai, Sântamaria de Piatra, Sighetu Marmației, Simeria Veche, Strei, Streisângeorgiu, Strei-Sacel, Țerova, Valea Sângeorgiului, Vinerea). 142 localities are of small size having less than 500 inhabitants, and from these 16 localities had in 1992 under 50 inhabitants (Boina 47, Boinita 18, Brestelnic 16, Căoi 11, Cicleni 33, Driștie 35, Dumești 24, Furcșoara 48, Gialacuta 30, Liborajdea 4, Lucacevăț 43, Martinovăț 22, Prislop 26, Valea Orevița 7, Valea Ravensca 43, Valea Mare de 
Criș 10). 85 localities are of medium size with population ranging from 501 1,500 inhabitants. Between 200-300 metres altitude, were in the year 1992, 20 large localities with population between 1,501-4,000 inhabitants (Băița, Bozovici, Călinești-Oaș, Câmpulung la Tisa, Certeju de Sus, Certeze, Dognecea, Glimboca, Nădrag, Obreja, Racșa, Remeți, Sarasău, Săpânța, Slatina-Timiș, Târșolț, Teliucu Inferior, Vadu Izei, Valea Hotarului, Vințu de Jos) together with 48,186 inhabitants.

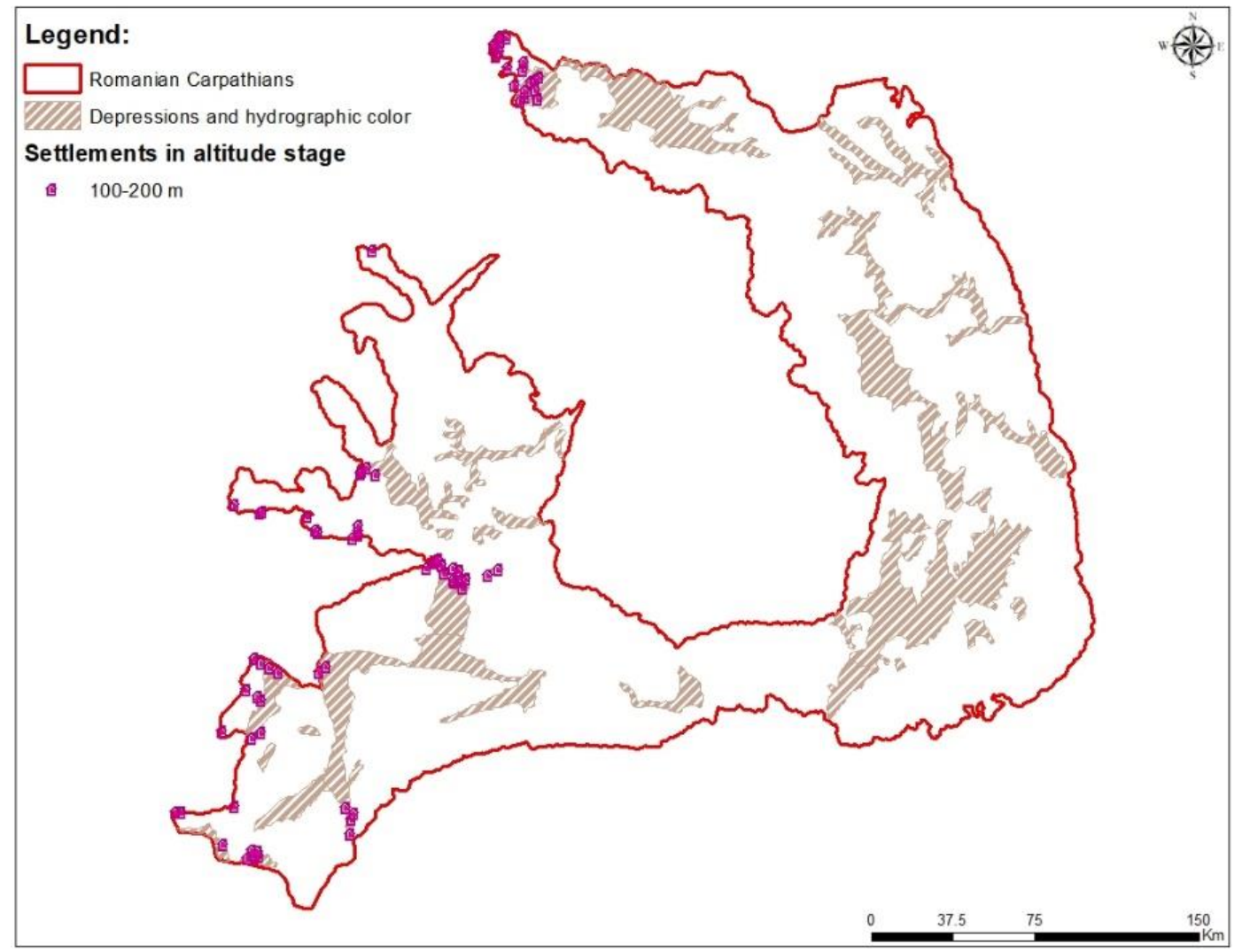

Figure 3. Distribution of settlements between 100-200 meters altitude (Source: own study)

In the population and housing census in the year 2011, the population located between 200-300 metres decreased by 100,689 . The decrease was $20 \%$, reaching 386,842 inhabitants. The population in the urban area decreased between 1992-2011 and 22\%, reaching 258,618 inhabitants, respectively a weight of $66 \%$. The population of settlements of less than 500 inhabitants increased by 41 localities in the 19 years, reaching 183. It is a visible depopulation of rural settlements in this altitudinal step. Of the 183 small settlements, 20 had in 2011, population below 50 inhabitants, and two localities registered 0 inhabitants (Boinița și Valea Orevița). The large settlements remained roughly the same as in 1992.

Settlements between 200-300 m extend to Carpathian depression (figure 4). In the north of the Carpathians, the settlements extend from the Oaşului Depression to the north-western parts of the Maramureş Depression. The largest 
aggrits are located in the Mureş corridor between Sebeş-Deva and the Hunedoara Depression, with the southern branch of the Hațegului Depression. The second visible habitat agitation, is in the Gurahonț-Hălmăgiu Depression in the Apuseni Mountains space. In the territory of the Banat Mountains we observe three depressions in which there are groups of settlements something more significant (Caransebeşului Depression, Reşiței Depression, Bozovici Depression).

And in the territories of these depressions there were demographic mutations due to the stages of colonization carried out by the authorities of those times. In the period 1736-1737, from Oltenia they migrated to Caransebes about 50 families of Bulgarian Catholics, who identified themselves as the pauliceni. In order to support them, the Caransebes authorities sent a letter to the Viennese Court requesting the agreement to grant agricultural land for 13 families of pauliceni. At Dognecea, were brought in the period 1727-1733, about 100 miners who had to activate in the mines of Dognecea and Moldova. To attract the miners, the administration gave them money in advance, granted them land to build houses and to practice agriculture (Țintă, 1972).

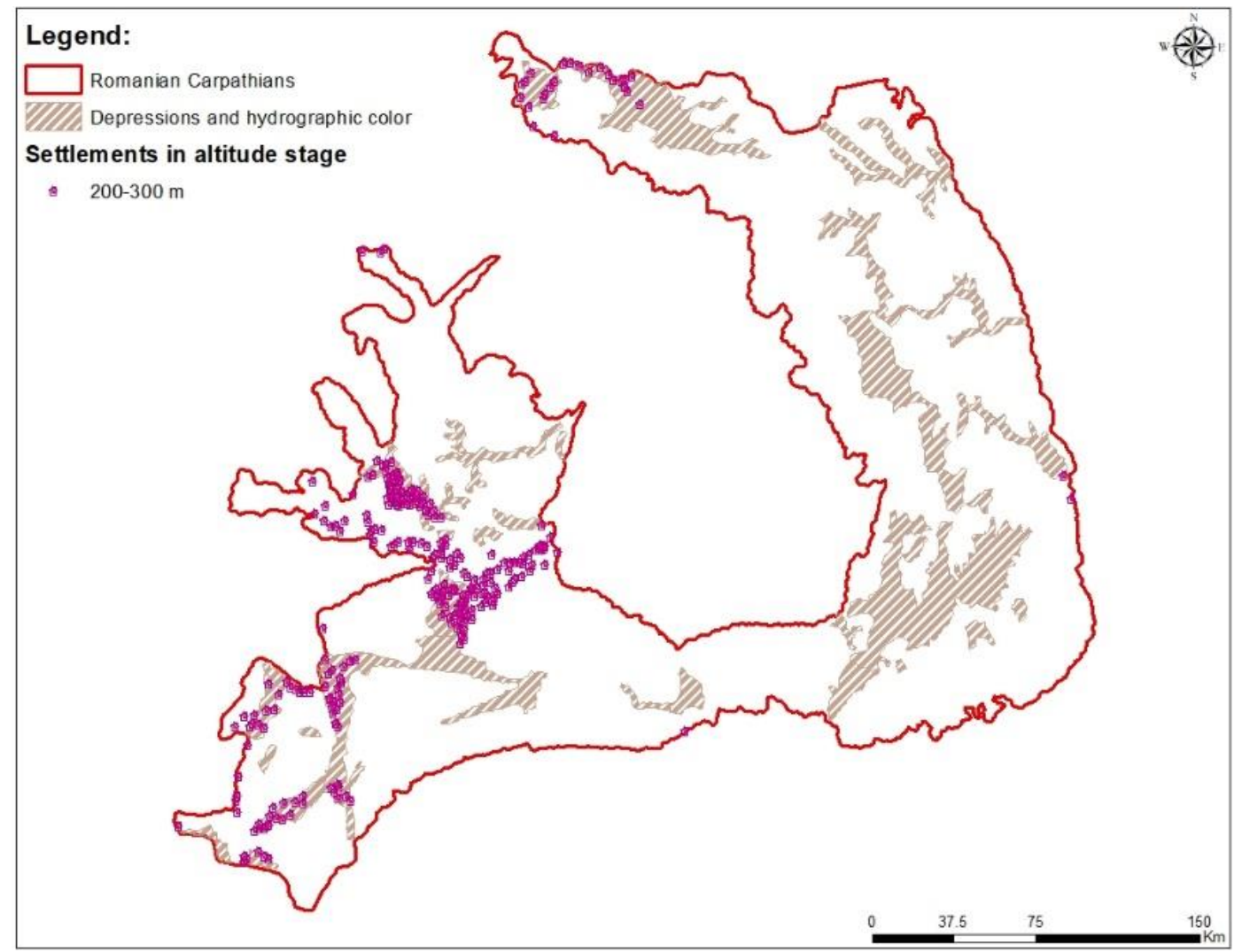

Figure 4. Distribution of settlements between 200-300 meters altitude (Source: own study)

The hypnosometric gear between 300-500 metres, incorporates 504 localities. Their population was in 1992 of 513,079 inhabitants. In the 46 cities lived 185,635 , representing $36 \%$ of the total population positioned between $300-$ 500 meters altitude. The Cugir was the largest urban settlement with 28,780 
inhabitants, and the smallest urban locality was Corbu with 56 inhabitants of Vâlcea County. 252 are small settlements below 500 inhabitants, being the most numerous. In 1992, the majority of the carpathian population between 300-500 meters lived in small settlements. 35 had fewer than 50 inhabitants. The number of large settlements that had between 1,501-4,000 inhabitants was 48 . The very large settlements of over 4,000 inhabitants were in number 6 . Of the 6 settlements, 5 (Bârsana, Ieud, Rona de Sus, Ruscova, Vişeu de Jos) are positioned in the Maramureş County, and one in Bistrița-Năsăud County (Maieru). The level of the higher economic and social status of Maramureș County led to agglutination of the demographic component in rural settlements of very large size. The total population of the 6 is 29,665 inhabitants, accounting for $5 \%$ of the total population of the year 1992 of the altimetry floor of 300-500 metres. 152 the settlements were of medium size, being the most numerous after small settlements. Many of the medium-sized ones were to decline demographics, and in 2011 they found themselves among small settlements.

The altitude threshold of 300-500 metres was depopulated between 19922011 and $16 \%$. The numerical loss was 85,772 people, reaching 42,7307 . Both in 1992 and 2011, the 300-500-metre gauge encapsulated the second largest demographic in the Romanian Carpathians. We note for the year 2011, the decline in urban populations at 147,234. Urban settlements depopulated by $20 \%$ compared with the year 1992. Also, the number of large settlements decreased from 1992 to 36, and the very large ones from 6 to 4 . From 1992 to 2011, there were two settlements that lost the inhabitants wholly (Bratova from Caraş-Severin County and Copaci in Hunedoara County).

Climbing to altitude, we see that settlements extend more, encompassing wider Carpathian territories (figure 5). The Depression of Maramureş are almost entirely contained, and descending to the Carpathian Curvature, we can identify several new settlements. This time the settlements are positioned on the eastern marginal parts of the Eastern Carpathians. They comprise the eastern extremity of the Bistriței and Trotuș corridor. Basically, there are settlements formed along the river courses, close to the contact between the Carpathians and the Subcarpathian. At these altitudes appear the first localities positioned in the Depression of Brasov, specifically in the Baraolt depressionary compartment. Similar example is the Depression of Loviştei and the corridor of Lotrului, the herd of localities being lifted. Hațegului Depression is fully comprised of settlements, forming a visible habitational group. We can also note the growing dispersion of settlements in the Apuseni Mountains, comprising deformation regions and the eastern part of the Arieşului corridor.

The most effective population of the Romanian Carpathians is between the altitudes of 500-750 meters. The 816 localities hold a population of $1,434,365$ inhabitants. Urban area consists of 62 urban settlements, in which 849,336 inhabitants live. The population in the urban environment represents $59 \%$ of the total population recorded between 500-750 meters altitude in the year 1992. The largest city in the demographic point of view is positioned in the carpathian curvature of the Romanian Carpathians. Brașov had in 1992, a total of the population of 323,736 inhabitants. At the opposite side, the smallest urban locality was Tirici from Hunedoara County with only 79 inhabitants. Settlements under 500 inhabitants dominate with 430 localities, of which 145 were in 1992 below 100 inhabitants. These localities under 100 inhabitants were at the beginning of the depopulation phenomenon, following the census of 2011, the 
population of settlements that had less than 100 inhabitants to grow more. The number of large settlements with population between 1,501-4,000 people is 89 . The population held by large settlements in the year 1992 was 212,186 , $14 \%$ of the total population located between 500-750 meters altitude. In 1992, there were 18 localities of very large size with over 4,000 inhabitants, positioned between 500-750 meters altitude (Teșila, Rucăr, Ghimbav, Prejmer, Zagon, Feldioara, Ghelința, Zemeș, Ciumani, Joseni, Remetea, Bistrița Bârgăului, Prundu Bârgăului, Rodna, Săcel, Moisei, Poienile de sub Munte, Repedea). All 18 very large localities are geographically positioned within the Eastern Carpathians and have together 97,964 inhabitants, representing $6 \%$ of the total population of the altitude threshold of 500-750 meters.

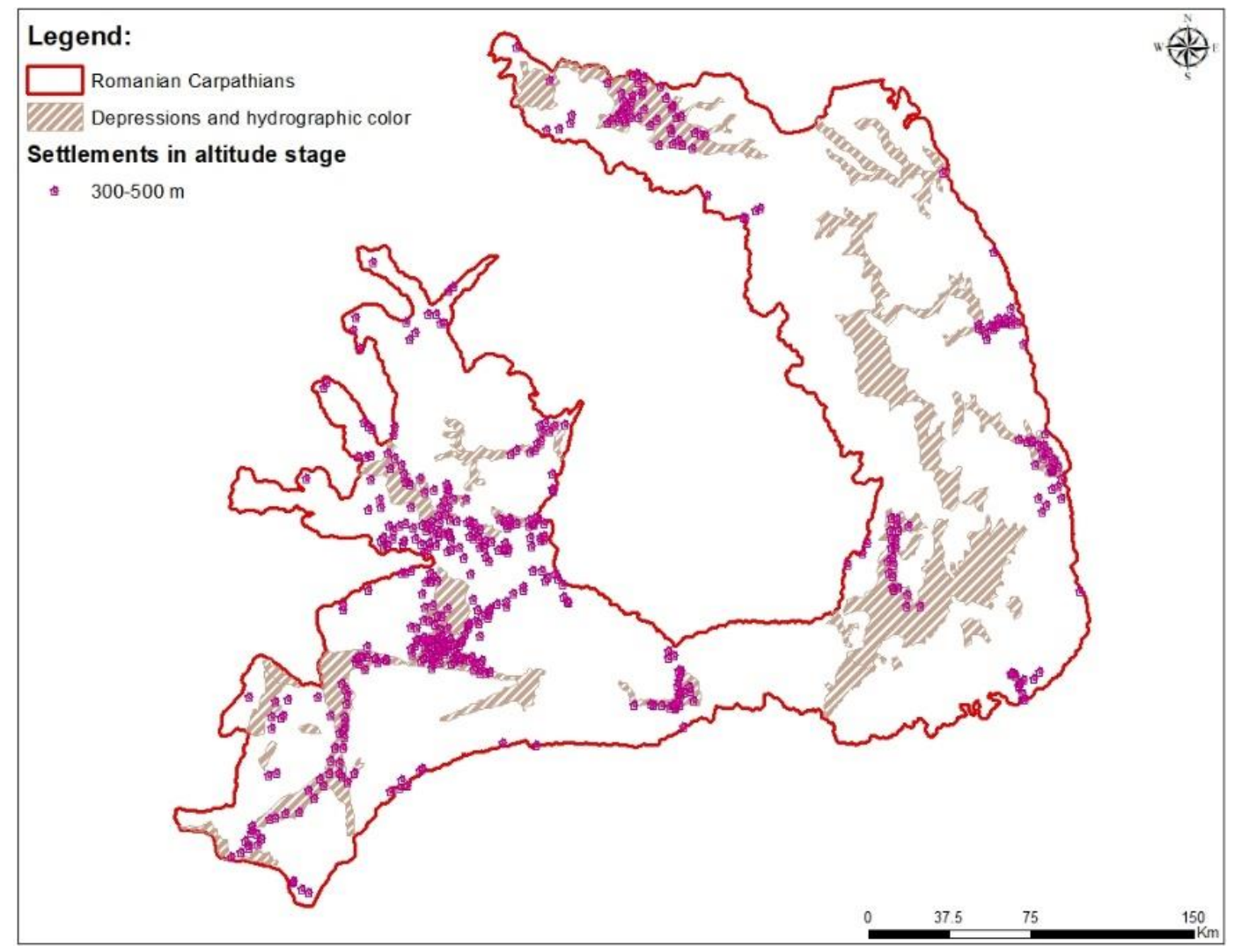

Figure 5. Distribution of settlements between 300-500 meters altitude (Source: own study)

Until the second census of the $21^{\text {st }}$ century, the population decreased by $10 \%$, reaching $1,284,216$ inhabitants. The loss of $10 \%$ meant a numerical demographic decrease of 150,149 inhabitants. Given the fact that it is the altitudinal step that cantonates the highest demographic in the Romanian Carpathians, the population decrease of $10 \%$ is the smallest compared to the other altitude steps. The urban population decreased by $14 \%$ reaching 726,366 inhabitants. Also, the share of the urban population reported in the total population in 2011 decreased from 1992 to 59\% to 56\%. Small-scale settlements were in 2011, 439, of which 182 under 100 inhabitants, and 9 had 0 inhabitants 
(Bunești, Geamăna, Gresia, Ibru, Mosoru, Roșia, Sasa, Tâmborești, Valea Uzului). The large settlements lost from 1992, 10 localities, being recorded in 2011, 79. The population held by the 79 large-scale settlements in 2011 was 186,112 inhabitants. Compared with 1992, the registered decrease was $12 \%$, losing 26,074 inhabitants. The very large localities that had over 4,000 inhabitants remained predominantly the same as in 1992. The exception is, two localities, Budila and Sânpetru who have passed from the large settlements, among the very large settlements in 2011. Tessila fell demographically by $11 \%$ in the 19 years, passing among large settlements in 2011. Thus, there were 19 settlements, which had in 2011, a total population of 100,185 inhabitants, registering 2\% increase compared to 1992.

At these altitudes, the majority of the Carpathian population lives (figure 6). Moreover, the distribution of settlements is a fairly uniform one, comprising each group of the Carpathians and almost every depression and river corridor. We note that this time the abundance of settlements is erected in the Eastern Carpathians, from the northern and southern deities and lanes. The habitat nuclei are predominantly carried out in the customs-Moldovian depression, descending towards the upper corridor of Bistrita, northern Giurgeu Depression. We note that the Ciucului Depression is completely covered, as well as the Depression of Brasov, with the density being somewhat higher in the eastern and central part. We can also see that the centre of the Apuseni Mountains is densely covered by settlements, being carried out in the upper basin of the Arieşului. The vast Petroşani coal basin comprises urban mining agglomerations, which we want to bring some important demographic data on the operation of mining activities.

The Austro-Hungarian authorities were very interested in the mining of this region, so they made demographic infusions. The colonised alohton population resulted in significant demographic increases in very short periods of time. From table 1 we can see that the demographic evolution of the administrative units constituting the Petroșani Depression (Petroşani coal basin) is an important one.

Table 1. Demographic evolutions in Petroșani Depression (Source: data processed after the NIS, Rotariu et al., 2011; Rotariu et al., 1999; Rotariu et al., 1997)

\begin{tabular}{|c|c|c|c|c|c|c|c|}
\hline $\begin{array}{c}\text { Administrative } \\
\text { unit }\end{array}$ & $\begin{array}{c}\text { Year } \\
\mathbf{1 8 8 0}\end{array}$ & $\begin{array}{c}\text { Year } \\
\mathbf{1 9 0 0}\end{array}$ & $\mathbf{\%}$ & $\begin{array}{c}\text { Year } \\
\mathbf{1 9 3 0}\end{array}$ & $\mathbf{\%}$ & $\begin{array}{c}\text { Year } \\
\mathbf{2 0 1 1}\end{array}$ & \% \\
\hline Petroșani & 5,755 & 11,152 & +93 & 18,211 & +63 & 37,160 & +104 \\
\hline Petrila & 3,226 & 4,497 & +39 & 10,496 & +133 & 22,692 & +116 \\
\hline Vulcan & 2,030 & 3,016 & +48 & 14,053 & +365 & 24,160 & +71 \\
\hline Lupeni & 1,244 & 5,393 & +333 & 15,093 & +179 & 23,390 & +54 \\
\hline Aninoasa & 738 & 1,070 & +44 & 5,318 & +397 & 4,360 & -18 \\
\hline Uricani & 1,677 & 1,306 & -22 & 1,848 & +41 & 8,972 & +385 \\
\hline Bănița & 1,331 & 1,776 & +33 & 1,734 & -2 & 1,211 & -30 \\
\hline Total & 16,001 & 28,210 & +76 & 66,753 & +136 & 121,945 & +82 \\
\hline
\end{tabular}




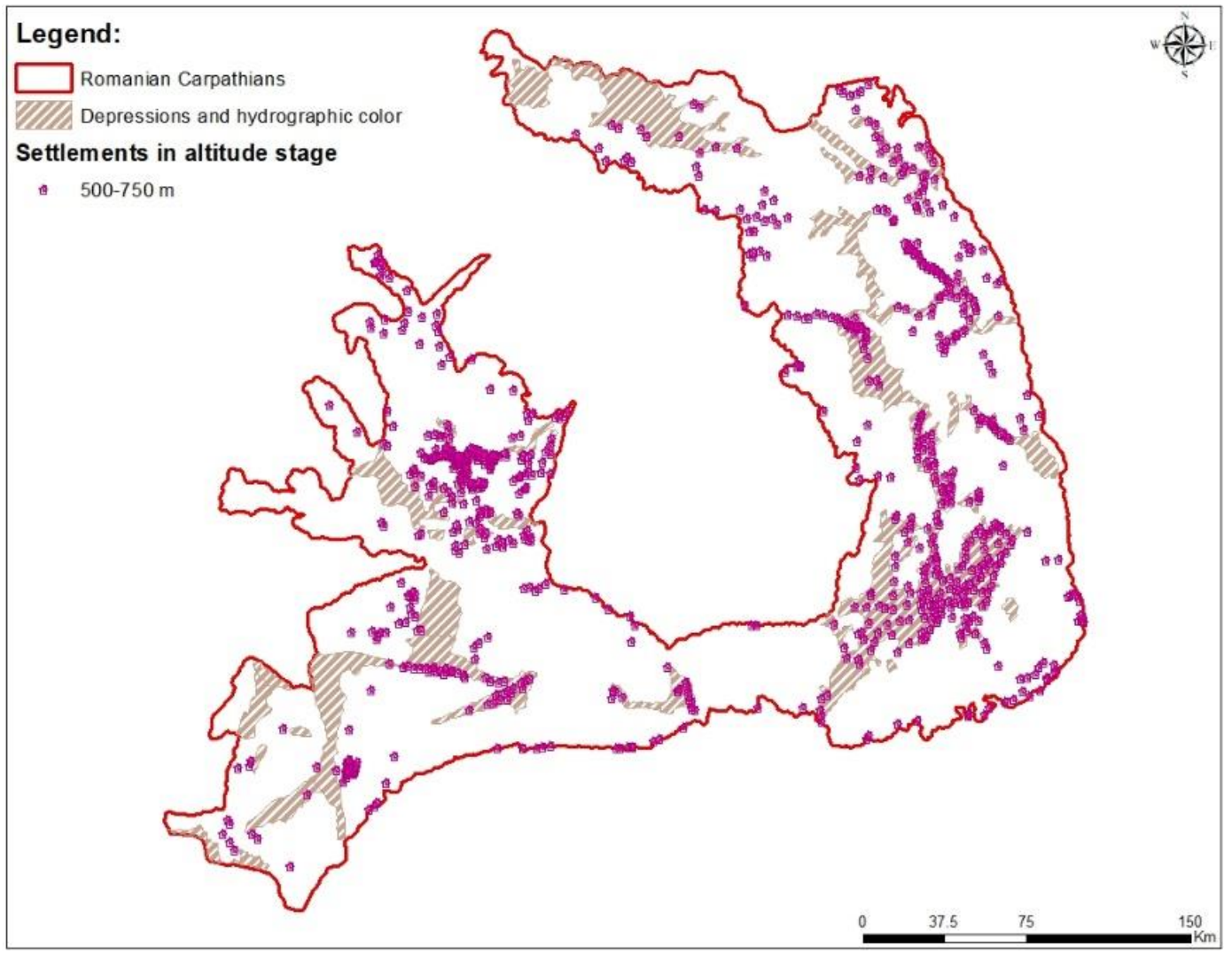

Figure 6. Distribution of settlements between 500-750 meters altitude (Source: own study)

Between 750-1,000 metres altitude there are 475 localities. At the last census of the twentieth century, they had a population of 247,444 inhabitants. The urban population between 750-1,000 metres was 1992, 97,156 inhabitants, incorporated in the space of 22 localities. The share of the urban population was 39\%. Both the largest (Gheorgheni 21,289 inhabitants) and the smallest (Visafolio 12 inhabitants) Demographical settlement were positioned in the Eastern Carpathians. With this hypnosometric floor they begin to dominate small settlements, especially those under 100 inhabitants and under 50 inhabitants. It is the altimetric gear from which the villages of the Apuseni Mountains begin. Thus, small settlements below 500 inhabitants are in number 366, representing $76 \%$ of the total settlements situated between $750-1,000$ meters altitude. Of these, 87 were between 50-100 inhabitants and 107 had under 50 inhabitants. The demographical total of the 366 localities was 1992, 46,140 inhabitants. Localities under 50 inhabitants had 2,895 inhabitants, and those between 50-100 had 6,055 inhabitants. The 107 localities with fewer than 50 inhabitants began from 1992, an extensive process of depopulation. Moreover, in 1992 there were registered four settlements with 0 inhabitants (Merişor and Surduc from Covasna County, Văseşti in Alba County, Iesle and Coasta Gubei in Suceava County). The number of medium-sized settlements with population between 501-1,500 inhabitants was 69. They incorporated in 1992 , a population of 51,204 people, and $20 \%$ of the total population between 
750-1,000 metres. 33,054 persons lived in 1992, in 15 localities of large size. In 1992, between 750-1,000 meters there were 3 very large localities whose population passed 4,000 inhabitants (Ditrău, Jina, Sândominic). The urban population reached 72,873 , decreasing by $24 \%$, compared to the last 20th Century Census. In 2011, the situation of small settlements between 750-1,000 meters was much changed. There were no fewer than 378 localities under 500 inhabitants, of which 173 with a population of less than 50 inhabitants and 70 with population between 50-100 inhabitants.

Their population was 2011 to 38,578 inhabitants, down by $17 \%$, compared with 1992. The number of localities with fewer than 50 inhabitants increased considerably in the 19 years, with 66 localities, from 107 to 173. Instead, localities with population between 50-100 inhabitants fell from 87 to 70 , so the population of 17 localities fell below 50 inhabitants. The population of 173 small localities was in 2011 of 3,791 inhabitants, increasing by 30\% compared to 1992. The population of localities that had no inhabitant in the 2011 Census increased from 1992. From 4 localities reached 21 (Ciumița, Dragu-Brad, Făgețel, Furduiești, Haiducești, Hosasău, Incești, Lăpușna, Lindenfeld, Preveciori, Gotești, Medrești, Mesteacăn, Petreni, Ticera, Țoci). The population of 70 settlements that had between $50-100$ inhabitants decreased by $14 \%$ to 5,196 inhabitants in 2011. The number of large settlements decreased to 13, and the demographical population decreased by $8 \%$. Settlements with population over 4,000 inhabitants were Ditrău, Sândominic who retained their positions as in 1992 and Băile Borșa. The Jina entered the large settlements, after during the 19 years lost $13 \%$ of the population. The total population between $750-1,000$ metres altitude decreased between 1992-2011 and 18\%.

This time, the dynamic component again occupies only a few territories (figure 7), extending to high mountain spaces such as the Poiana Rusca Mountains, the Şureanu Mountains and the Harghita Mountains. By far the most visible core of settlements is positioned in the Apuseni Mountains space, where the very small villages with scattered structure dominate. In the Eastern Carpathians, the settlements are grouped more comapct in the Dornelor Depression and Giurgeului Depression.

The least populated throughout the period was the altitudinal step of 1,000-1,500 meters. However, the number of settlements is high at these altitudes 146 localities. Most of them are villages of the Apuseni Mountains, representing the continuity of the distribution of villages from the previous altitudinal step. In 1992, the total population contained in this altitudinal step was only 32,084 people. The population in the urban area was 6,384 inhabitants, comprised of 5 urban localities. Thus, urban settlements concentrated $20 \%$ of the total population. The specificity of these altitudes is given by the dominance of settlements below 500 inhabitants. Another specificity is given by the permanent dwelling character, and the settlements between 1,000-1,500 meters altitude face high isolation. One of the major causes of isolation can be said to be the lack of transport infrastructure, reduced accessibility due to high altitude. Also, geomorphological restrictivity occurs through the degree of fragmentation, declivity and fragmentation density. Geomorphological restriction is required as a disperise factor of settlements by geographical position, large distance between households. Basically, these smallscale localities have a scattered structure, depending on the morphological, hydrice, edaphic conditions. Of the total of 146 settlements, not less than 130 
were under 500 inhabitants in 1992. Of these, 38 had less than 50 inhabitants, and 35 had between 50-100 inhabitants. The population incorporated by the 38 was in 1992 of 1,075 inhabitants (3\%), and the 35 had 2,621 inhabitants (8\%). In 1992, the population of the 130 small localities was 14,913 inhabitants, representing $46 \%$ of the demographical population between 1,000-1,500 metres. The village of Mărişel in the Apuseni Mountains was the only large size, with 1,951 inhabitants, the rest being middle-sized localities.

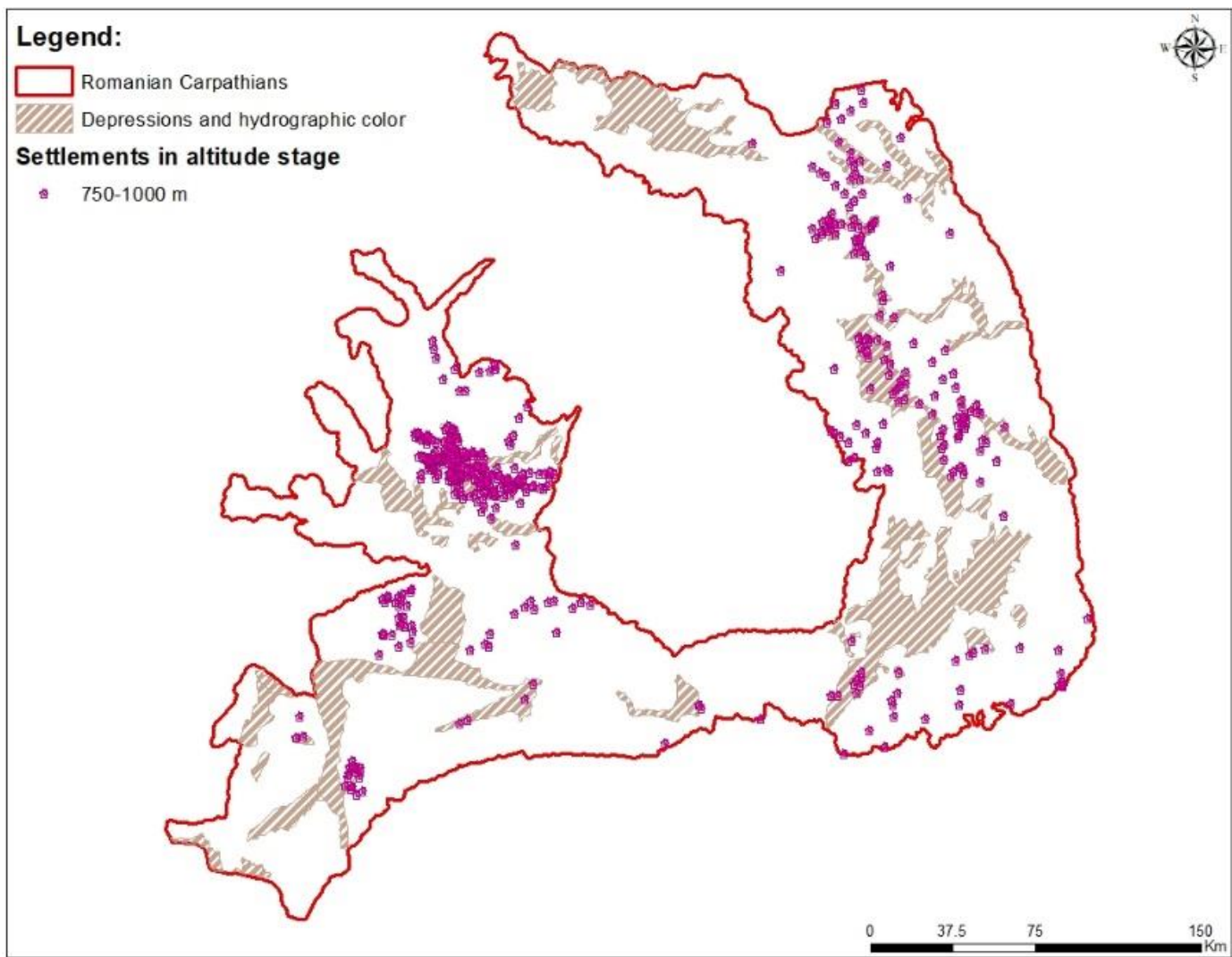

Figure 7. Distribution of settlements between 750-1000 meters altitude (Source: own study)

By 2011 , the population at these altitudes decreased by $26 \%$, registering 23,573 inhabitants. The urban population decreased sharply by $39 \%$ in the 19 years, reaching 3,892 inhabitants. The gradual loss of tourist function resulted in the progressive depopulation of urban localities. Compared to 1992, the number of small localities increased to 134, with localities that have completely depopulated with 0 inhabitants (Bordeștii Poieni, Crinț, Hărăști, Poieni in Alba County and SSesuri in Suceava County). This time, there was no large locality, the one in 1992, passing among the medium-sized.

This last altitudinal step of the Romanian Carpathians is characteristic of mountain villages in the Apuseni Mountains (figure 8). Basically, these villages have a permanent dwelling character, having a high degree of isolation. The lack of access infrastrucutation makes the winter season access to these settlements very difficult or even impossible. The settlements at these altitudes in the other 
mountain groups have a more seasonal character, with the function of shelter when people climb with animals to grazing.

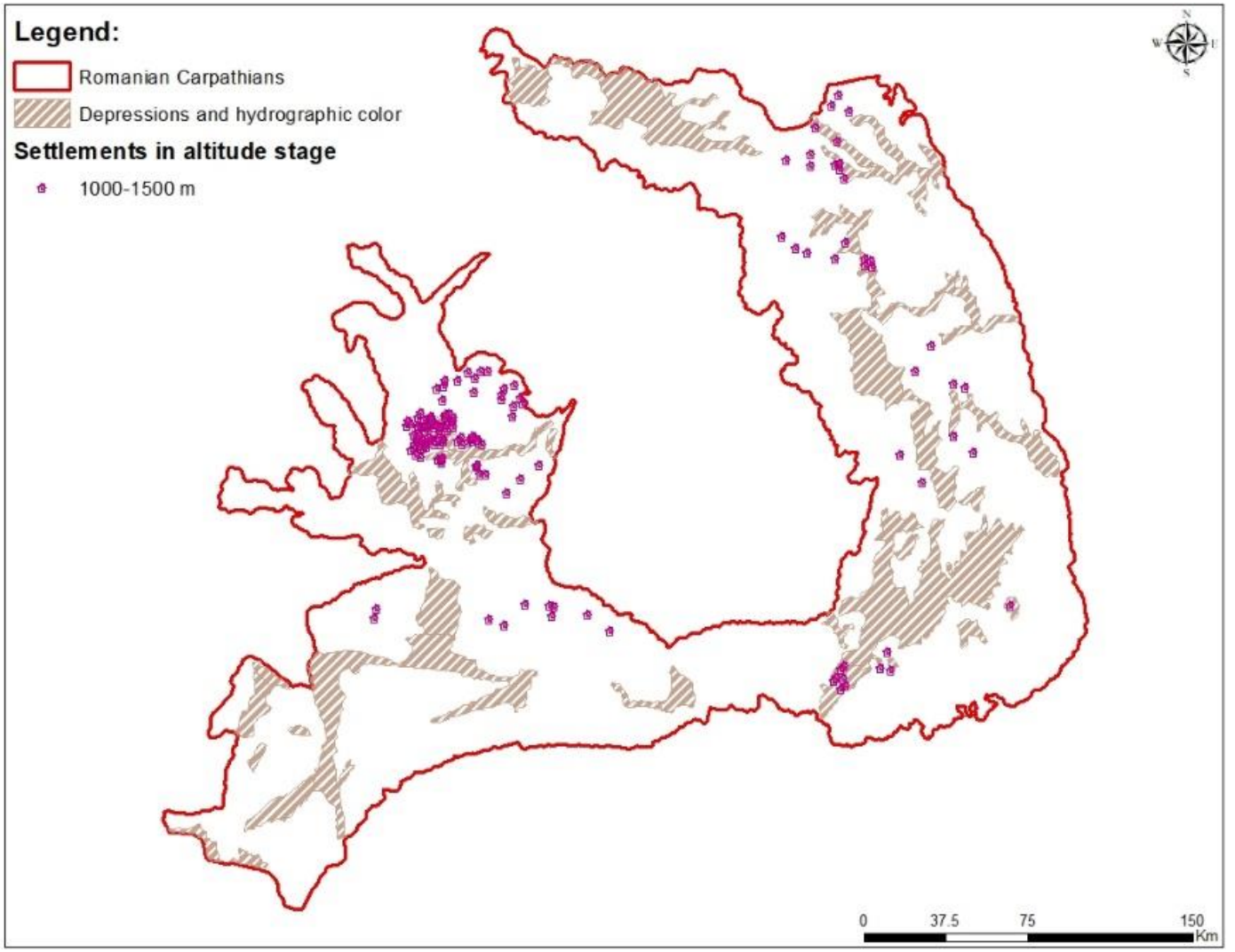

Figure 8. Distribution of settlements between 1000-1500 meters altitude (Source: own study)

\section{CONCLUSIONS}

The Romanian Carpathians depopulated in the period 1992-2011, with about 435,000 inhabitants. Each of the 7 altitudinal classes decreased numerically in the period 1992-2011 (figure 9). The 7 altitude classes decreased demographical, with weights between $10 \%-27 \%$ (figure 10). The majority of the population is located between 500-750 metres, which is lost to the highest numerical demographic, about 150,000 inhabitants. $35 \%$ of the localities of the Romanian Carpathians are located between 500-750 meters. It is worth noting that the large share of $21 \%$ have localities positioned between 750-1,000 meters altitude (figure 11). Under percentage ratio, the largest demographic decrease was $27 \%$ for settlements between 56-100 meters altitude. They have a share of only $1 \%$ of the total carpathian settlements. Both urban and rural areas are systematically depopulated between 1992-2011. As a consequence, the space of the Romanian Carpathians faces risk demographic phenomena, such as depopulation. 


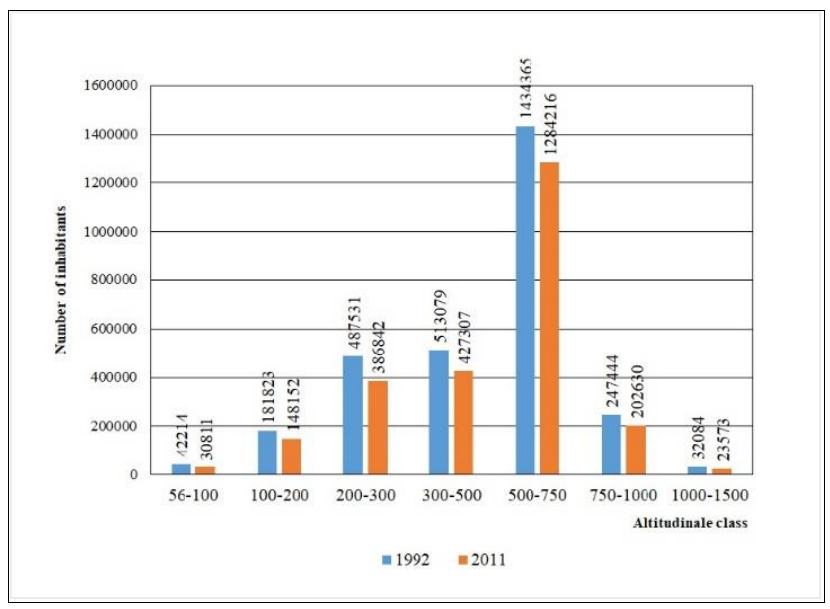

Figure 9. Numerical evolution of the population on the 7 elevation classes (Source: data processed after the NIS)

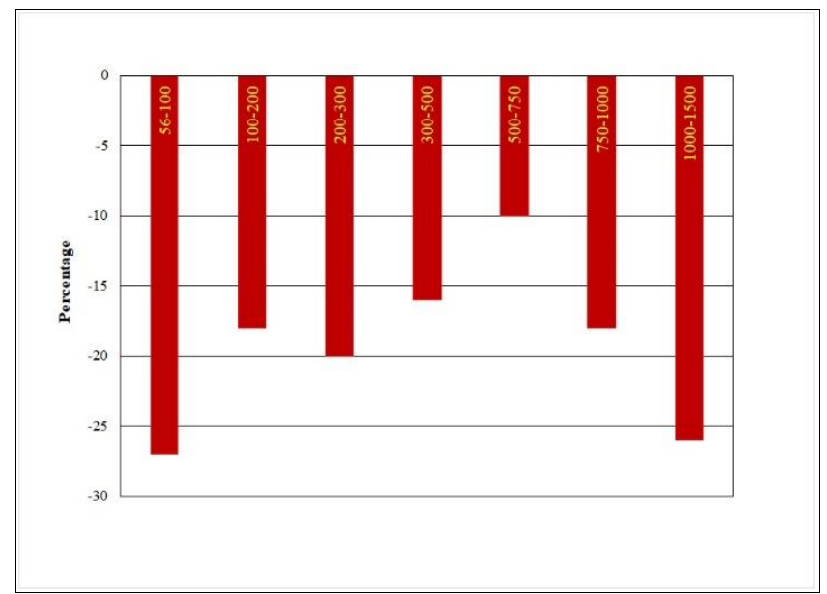

Figure 10. Percentage evolution of the population on the 7 elevation classes from 1992 to 2011 (Source: data processed after the NIS)

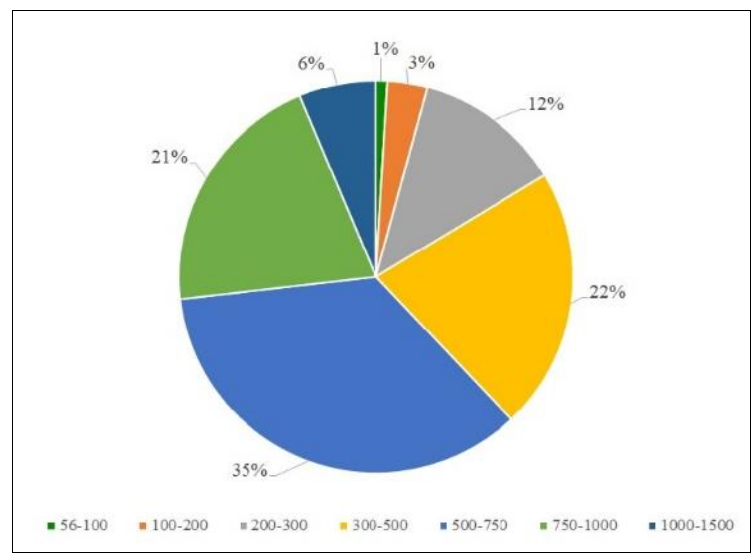

Figure 11. The share of settlements on the 7 altitude classes (Source: own study) 


\section{REFERENCES}

Alexandrescu, V. (1995). Depresiunea Petroşani : studiu de geografie a aşezărilor umane [Petroşani Depression: Geography Study of human settlements], Editura Universității Bucureşti, București.

Arsenović, D., Đurđev, B., Ivkov-Džigurski, A. (2009). The ageing of population in Kanjiza municipality. Bulletin of the Serbian Geographical Society, 89(3), 103-113.

Bizerea, M. (1970). Populația şi aşezările omeneşti din Banat [Human population and settlements in Banat], Editura Centrul de Multiplicare al Universității din Bucureşti, București.

Constantin, V. (2011). Aşezările din arealele miniere din Munții Apuseni: studiu de geografie aplicată [Settlements in the Apuseni Mountains mining areas: Applied Geography Study], (Doctoral dissertation).

Djurkin, D. (2018). Types of changes of population development of settelments in South Banat. Bulletin of the Serbian Geographical Society, 98(1), 91-120.

Findlay, A. M. (2003). Population geographies for the $21^{\text {st }}$ century. Scottish Geographical Journal, $119(3), 177-190$.

Herman, G. V. (2008). Quantitative Distribution of Human Settlements in Somes Plain. Analele Universității din Oradea, Seria Geografie, 28,144-149.

Herman, G. V. (2009). Omul şi modificările antropice din Câmpia Someşului [The man and anthropogenic changes in Somes Plain], Editura Universității din Oradea, Oradea, Romania.

Holircă, B. C. (2014). Populația din Depresiunea Ciuc şi zona de gravitație montană [The population of the Ciuc Depression and the area of mountain gravity], (Doctoral dissertation).

Ionescu, N. D. (2009). Populația şi aşezările din Dealurile Someşului Mare [The population and settlements of the Someşului Mare Hills], (Doctoral dissertation).

Josipovic, D., \& Repolusk, P. (2003). Demographic Characteristics of the Romany in Prekmurje. Acta Geographica Slovenica, 43(1), 127-147.

Kerbler, B. (2015). Population aging in Slovenia: A spatial perspective. Acta Geographica Slovenica, 55(2), 303-317.

Lung, M-S. (2018). The natural dynamics of the rural population in Apuseni Mountains (2011 Census). Revista Românã de Geografie Politică, 20(2), 41-48.

Lung, M-S., \& Gligor, V. (2018). Demographic changes in the urban space of Apuseni Mountains. Analele Universitătii din Oradea, Seria Geografie, 28(2), 64-173.

Lung, M-S., \& Mureșan, G-A. (2018). Caracteristici demografice ale orașelor mici din județul CarașSeverin în perioada postcomunistă (1992-2011) [Demographic characteristics of small towns in Caraş-Severin County in the post-communist period]. Geographia Napocensis, 12(1), 7-15.

Maier, A. (2001). Podişul Someşan: populația şi aşezarile [Someşan Plateau: population and settlements], Editura George Barițiu, Cluj-Napoca.

Misachevici, A. (2012). Populația şi aşezările din Depresiunea Sibiului [Population and settlements in Sibiu Depression], Editura Techno Media, Sibiu.

Niță, A-F. (2007). Populația şi aşezările din Depresiunea Braşov [Population and settlements in Brașov Depression], (Doctoral dissertation).

Popa-Bota, H. (2003). Organizarea spațiului geografic in Depresiunea Maramureşului [Organization of geographic space in the Depressions of Maramureş], (Doctoral dissertation).

Posea, G., \& Badea, L. (1984). România. Unitățile de relief (Regionarea geomorfologică) [Romania. Relief units (geomorphological regionation)], Editura Științifică și Enciclopedică, București.

Prioux, F., \& Mazuy, M. (2009). Recent Demographic Developments in France: Tenth Anniversary of the PACS Civil Partnership, and Over a Million Contracting Parties. Population, 64(3), 393442.

Rațiu, R. F. (2008). Populația şi aşezările din Câmpia Someşană (Câmpia Transilvaniei) [Population and settlements in the Someşana Plain (Transylvanian Plain)], Editura Casa Cărții de Ştiință, Cluj-Napoca.

Rotariu, T-I., Mureşan, C., Semeniuc, M. (1997). Recensământul din 1880, Transilvania (Census of 1880, Transylvania), Editura Staff, București.

Rotariu, T-I., Semeniuc, M., Mezei, E. (1999). Recensământul din 1900, Transilvania (Census of 1900, Transylvania), Editura Staff, Bucureşti.

Rotariu, T-I., Semeniuc, M., Mezei, E., Moga, M., Şomfelean, L., Poledna, R. (2011). Recensământul din 1930, Transilvania (Census of 1930, Transylvania), Editura Presa Universitară Clujeană, Cluj-Napoca.

Seer, M. (2004). Aşezările şi organizarea spațiului geografic în Depresiunea Giurgeului [Settlements and organization of geographic space in Giurgeului Depression], (Doctoral dissertation).

Stroia, M. (2001). Podișul Secașelor : populația și așezările umane [Secaselor Plateau: population and human settlements], Editura Buna Vestire, Blaj. 
Surd, V. (1993). Aşezările din bazinul montan al Arieşului: studiu de geografie aplicată [Settlements in the mountain basin of the Ariesului: Applied Geography Study], Editura Interferențe, ClujNapoca.

Tănasă, E. (2007). Populația şi aşezările din Câmpia Mureşană (Câmpia Transilvaniei) [The population and settlements of the Mureşan Plain (Transylvanian Plain)], (Doctoral dissertation).

Țintă, A. (1972). Colonizările habsburgice în Banat: 1716-1740, Editura Facla, Timișoara.

Živković, D., \& Pavlović, M. (2006). Changes in number of population, households and population density in Tutin area. Bulletin of the Serbian Geographical Society, 86(1), 97-104.

*** Recensämântul populatiei și al locuințelor din anul 2011 [Census of Population and Dwellings of the year 2011], Institutul Național de Statistică, București, Retrieved from http://statistici.insse.ro/shop/ .

*** Recensământul populației și al locuințelor din anul 1992 [Census of Population and Dwellings of the year 1992], Institutul Național de Statistică, București, Retrieved from http://statistici.insse.ro/shop/ .

Submitted:

November 19, 2018
Revised:

February 27, 2019
Accepted and published online: March 25, 2019 